\title{
Sports Research Trends in the Last 10 Years: Information to Librarians, Researchers, and Policy Makers
}

\author{
Nurhasan Nurhasan, Binar Kurnia Prahani, Nadi Suprapto, Beni Setiawan, \\ Utama Alan Deta, Muchamad Arif Al Ardha
}

Universitas Negeri Surabaya, Jl. Lidah Wetan 60213, Surabaya, Indonesia

\begin{abstract}
Currently, librarians, researchers, and policy maker still need updated information regarding the profile of research trends, especially in sports. This research aims specifically to explore sports research trends. Publication (Scopus) at the International Level is dominated by scientific journal articles, while the Indonesian level is dominated by Conference Papers (Proceedings). The opportunity for publication in Scopus indexed scientific journals is still wide open. The research implications: (1) contribute ideas to librarians, researchers, and policy maker in the world to be able to develop sports and be able to produce Scopus documents (reputable journals) to the fullest; (2) providing ideas for librarians, researchers, and policy maker regarding sports research trends; and (3) providing information on research trend profiles from Scopus documents related to international and Indonesian sports to librarians, researchers, and policy maker.
\end{abstract}

Keywords - librarian, policy maker, researcher, research trend, sports.

\section{Introduction}

Sport has become a top study in the last ten years. Recent research results show that the field of sports

DOI: 10.18421/TEM111-36

https://doi.org/10.18421/TEM111-36

Corresponding author: Binar Kurnia Prahani,

Universitas Negeri Surabaya, Jl. Lidah Wetan 60213,

Surabaya, Indonesia

Email: binarprahani@unesa.ac.id

Received: 01 December 2021.

Revised: 05 February 2022.

Accepted: 09 February 2022.

Published: 28 February 2022.

(cc)BY-NC-ND (C) 2022 Nurhasan Nurhasan et al; published by UIKTEN. This work is licensed under the Creative Commons Attribution-NonCommercial-NoDerivs 4.0 License.

The article is published with Open Access at https://www.temjournal.com/ still needs to be explored and explored more deeply [1], [2], [3]. Other countries can adopt innovations in sports in the development of sports achievements, one of which is by looking at the latest trend profiles in sports research [4], [5] through the Scopus document. In this case, librarians and researchers have the opportunity to contribute significantly to the advancement of the sports field in their country. This is because librarians and researchers are at the forefront of developing innovation and contributing ideas to policy makers.

Scopus is a reputable international index. Based on the Scopus database with the keyword sports science from 2012 to 2021, 41,871 Scopus indexed documents are shown in Figure 1. As a comparison, in Indonesia, where sports are the leading favorite entertainment, there are not many Scopus documents. Conditions in Indonesia alone in the publication on Scopus include 1,089 Scopus documents for all research fields as of November 29, 2021 (www.scopus.com). Even though research and innovation need to be published in reputable international journals, one of which is the Scopus index standardized at the international level.

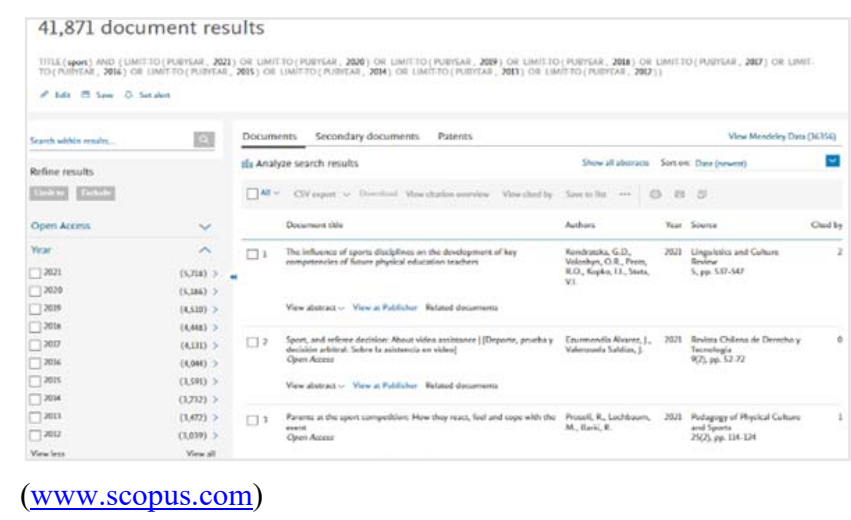

Figure 1. Scopus title "sport" document from 2012-2021* (as of November 29, 2021)

In fact, in Indonesia, publications on journal indexed Scopus are still low [6], especially in sport. Indonesia is not in the top 10 at the international level. It is also relevant to the State University of 
Surabaya (i.e., Indonesia), where publications at Scopus are also still low. It can be used as material for strengthening publications within the sports faculty at the international level and in Indonesia. We know that sports is one of the research fields evenly distributed globally, but its publication is still low compared to other general fields. The results of limited interviews with several lecturers at the State University of Surabaya (i.e., Unesa) related to the factors causing the low publication of Scopus, namely: (1) Sports lecturers are accustomed to activities in the field; (2) The climate for scientific publications within the sports faculty, especially for reputable international journals, is still low; (3) The culture of publishing research results has not been optimized in reputable international journals; (4) There are still many sports lecturers who cannot determine a reputable international journal that is safe. In addition, Unesa also does not have documents related to sports research trends based on the Scopus database. Based on the problems above, it is essential to find sports research topics that are excellent in Scopus Publications. It is hoped that the results of this research can be the first bridge for researchers to develop sports in environment and produce Scopus documents to the fullest.

\subsection{Research Objective}

The primary purpose of this research is to explore sports research trends. The Scopus document's research trends will be explored: sports at the International and Indonesian levels.

\subsection{Research Urgency}

There is a need for research to find sports research topics that are trending in the Scopus database. It will be the first bridge for librarians and researchers. This is because librarians and researchers are at the forefront of developing innovation and contributing ideas to policy makers.

\section{Research Methods}

The research uses bibliometrics. There are three components of bibliometrics, namely: a) bibliometrics for bibliometrics, which is the primary domain of bibliometric research and is traditionally used as a research methodology; b) bibliometrics for scientific disciplines (scientific information), considering that researchers work is scientifically oriented, their interest is influential in their field of specialization and allows for a joint borderland with quantitative research in information retrieval; c) bibliometrics for science policy and management (science policy), is the domain of research evaluation in various research topics [7], [8]. This study uses reputable international publication data sourced from the Scopus database (www.Scopus.com). Data collection through a search for publications on Scopus with the keyword sport with the article title category in the period $2012-2021$ * (as of November 29, 2021). Research trends from the Scopus document will be explored, namely: sports at the international and Indonesian levels. The results of the Scopus database will be visualized using VOSviewer. The VOSViewer application is used to describe and derive novelty from sports research [9], [10], [11].

\section{Results and Discussion}

\subsection{Publication Output and Subject Area}

There are 149,905 document articles in the Scopus journal relevant to sport in the last ten years (20122021). For the Indonesian level, there are 1,089 documents. In general, at the international and Indonesian levels. The top 10 subject areas at the global and Indonesian levels are presented in Table 1 .

Table 1. Subject areas in research on sports topics

\begin{tabular}{|l|c|l|c|}
\hline \multicolumn{2}{|c|}{ International (149.905 Doc.) } & \multicolumn{2}{|c|}{ Indonesia (1.089 Doc.) } \\
\hline Subject Area & Total & Subject Area & Total \\
\hline Medicine & 71.167 & Engineering & 490 \\
\hline $\begin{array}{l}\text { Health } \\
\text { Professions }\end{array}$ & 37.455 & $\begin{array}{l}\text { Materials } \\
\text { Science }\end{array}$ & 352 \\
\hline Social Sciences & 29.379 & $\begin{array}{l}\text { Physics and } \\
\text { Astronomy }\end{array}$ & 171 \\
\hline Engineering & 16.218 & $\begin{array}{l}\text { Computer } \\
\text { Science }\end{array}$ & 171 \\
\hline $\begin{array}{l}\text { Computer } \\
\text { Science }\end{array}$ & 14.154 & Medicine & 164 \\
\hline Psychology & 11.511 & Social Sciences & 151 \\
\hline $\begin{array}{l}\text { Business, } \\
\text { Management, } \\
\text { and Accounting }\end{array}$ & 9.277 & $\begin{array}{l}\text { Health } \\
\text { Professions }\end{array}$ & 103 \\
\hline $\begin{array}{l}\text { Biochemistry, } \\
\text { Genetics and } \\
\text { Molecular } \\
\text { Biology }\end{array}$ & 8.492 & $\begin{array}{l}\text { Environmental } \\
\text { Science }\end{array}$ & 74 \\
\hline $\begin{array}{l}\text { Arts and } \\
\text { Humanities }\end{array}$ & 7.222 & $\begin{array}{l}\text { Business, } \\
\text { Management, } \\
\text { and Accounting }\end{array}$ & 64 \\
\hline $\begin{array}{l}\text { Environmental } \\
\text { Science } \\
\text { Giochemistry, } \\
\text { Molecular } \\
\text { Biology }\end{array}$ & 62 \\
\hline
\end{tabular}


Table 1 shows that the subject area of the sports topic at the international level is dominated by medicine, health professions, and social science. Engineering and Material Science dominate Indonesia's number 1 and 2. It is in line with the Document Type at the Indonesian and Unesa levels that are dominated by proceedings.

\subsection{Document Type, Source Type, dan Source Title}

Sport research topics in the last ten years (20122021) based on Scopus documents refer to Document type is presented in Table 3, Source Type in Table 3, and Source Title in Table 4.

Table 2. Document Type in research on sports topics

\begin{tabular}{|l|c|l|c|}
\hline \multicolumn{2}{|l|}{ International (149.905 Doc.) } & \multicolumn{2}{l|}{ Indonesia (1.089 Doc.) } \\
\hline Document type & Total & Document type & Total \\
\hline Article & 104.444 & $\begin{array}{l}\text { Conference } \\
\text { Paper }\end{array}$ & 684 \\
\hline Conference Paper & 15.650 & Article & 380 \\
\hline Review & 12.143 & Book Chapter & 12 \\
\hline Book Chapter & 7.295 & Review & 9 \\
\hline Editorial & 2.998 & Letter & 2 \\
\hline
\end{tabular}

Table 2 describes Sport research topics in the last ten years (2012-2021) based on document type at the international level, dominated by articles. This is compared to the Indonesian group, which was dominated by the Conference Paper (Proceedings). This is also expanded with Source Type-based data presented in Table 3.

Table 3. Source Type in research on sports topics

\begin{tabular}{|c|c|c|c|}
\hline \multicolumn{2}{|c|}{$\begin{array}{c}\text { International } \\
(\mathbf{1 4 9 . 9 0 5} \text { Doc.) }\end{array}$} & \multicolumn{2}{c|}{$\begin{array}{c}\text { Indonesia } \\
(\mathbf{1 . 0 8 9} \text { Doc.) }\end{array}$} \\
\hline Source type & Total & Source type & Total \\
\hline Journal & 124.783 & $\begin{array}{c}\text { Conference } \\
\text { Proceeding }\end{array}$ & 676 \\
\hline $\begin{array}{c}\text { Conference } \\
\text { Proceeding }\end{array}$ & 11.794 & Journal & 392 \\
\hline Book & 8.236 & Book Series & 14 \\
\hline Book Series & 4.524 & Book & 6 \\
\hline Trade & 453 & $\begin{array}{c}\text { Trade } \\
\text { Journal }\end{array}$ & 1 \\
\hline
\end{tabular}

Table 3 describes the research topics of sport in the last ten years (2012-2021) based on Source type at the international level dominated by Journals. This is inversely proportional to the level of Indonesia and Unesa, which were overlooked in the Conference Proceedings. This is also expanded by the Source Title-based data presented in Table 4.
Table 4. Source Title on research on sports topics

\begin{tabular}{|c|c|c|c|}
\hline \multicolumn{2}{|c|}{$\begin{array}{l}\text { International } \\
\text { (149.905 Doc.) }\end{array}$} & \multicolumn{2}{|l|}{$\begin{array}{c}\text { Indonesia } \\
\text { (1.089 Doc.) }\end{array}$} \\
\hline Source Title & Total & Source Title & Total \\
\hline $\begin{array}{l}\text { Teoriya I Praktika } \\
\text { Fizicheskoy } \\
\text { Kultury }\end{array}$ & 2.312 & $\begin{array}{l}\text { IOP Conference } \\
\text { Series Materials } \\
\text { Science And } \\
\text { Engineering }\end{array}$ & 339 \\
\hline $\begin{array}{l}\text { British Journal of } \\
\text { Sports Medicine }\end{array}$ & 1.876 & $\begin{array}{l}\text { Journal of Physics } \\
\text { Conference Series }\end{array}$ & 139 \\
\hline $\begin{array}{l}\text { International } \\
\text { Journal of } \\
\text { Environmental } \\
\text { Research And } \\
\text { Public Health }\end{array}$ & 1.575 & $\begin{array}{c}\text { International } \\
\text { Journal of Human } \\
\text { Movement And } \\
\text { Sports Sciences }\end{array}$ & 46 \\
\hline $\begin{array}{c}\text { American Journal } \\
\text { of Sports } \\
\text { Medicine }\end{array}$ & 1.367 & $\begin{array}{l}\text { IOP Conference } \\
\text { Series Earth And } \\
\text { Environmental } \\
\text { Science }\end{array}$ & 40 \\
\hline $\begin{array}{c}\text { Journal of } \\
\text { Strength And } \\
\text { Conditioning } \\
\text { Research } \\
\end{array}$ & 1.238 & $\begin{array}{c}\text { Journal of Physical } \\
\text { Education And } \\
\text { Sport }\end{array}$ & 19 \\
\hline $\begin{array}{l}\text { Medicine And } \\
\text { Science In Sports } \\
\text { And Exercise }\end{array}$ & 1.192 & $\begin{array}{l}\text { AIP Conference } \\
\text { Proceedings }\end{array}$ & 17 \\
\hline $\begin{array}{c}\text { Journal of Sports } \\
\text { Sciences }\end{array}$ & 1.189 & $\begin{array}{l}\text { Asian Social } \\
\text { Science }\end{array}$ & 11 \\
\hline $\begin{array}{c}\text { Journal of } \\
\text { Physical } \\
\text { Education And } \\
\text { Sport } \\
\end{array}$ & 1.166 & $\begin{array}{c}\text { Advanced Science } \\
\text { Letters }\end{array}$ & 8 \\
\hline $\begin{array}{c}\text { Orthopaedic } \\
\text { Journal of Sports } \\
\text { Medicine }\end{array}$ & 1.159 & $\begin{array}{c}\text { Indian Journal of } \\
\text { Public Health } \\
\text { Research And } \\
\text { Development } \\
\end{array}$ & 8 \\
\hline Plos One & 1.073 & $\begin{array}{c}\text { Open Access } \\
\text { Macedonian } \\
\text { Journal of Medical } \\
\text { Sciences }\end{array}$ & 8 \\
\hline
\end{tabular}

Table 4 describes the research topics of sport in the last ten years (2012-2021) based on Source Title (top $10)$ at the international level dominated by scientific journal articles. It contrasts the Indonesian level, which was dominated by the Conference Paper (Proceedings). The top 10 source titles at the Indonesian level are held by (1) IOP Conference Series Materials Science and Engineering, (2) Journal of Physics Conference Series, and (3) ACM International Conference Proceeding Series. In the top ten, there are no documents from the proceedings.

\subsection{Affiliation dan Keyword}

Sport research topics in the last ten years (20122021) based on Scopus documents referring to Affiliation are presented in Table 5 and keywords in Table 6 . 
Table 5. Affiliation in research on sports topics

\begin{tabular}{|c|c|c|c|}
\hline \multicolumn{2}{|c|}{$\begin{array}{c}\text { International (149.905 } \\
\text { Doc.) }\end{array}$} & \multicolumn{2}{|c|}{ Indonesia (1.089 Doc.) } \\
\hline Affiliation & Total & Affiliation & Total \\
\hline $\begin{array}{l}\text { Loughborough } \\
\text { University }\end{array}$ & 1.281 & $\begin{array}{l}\text { Universitas } \\
\text { Pendidikan } \\
\text { Indonesia }\end{array}$ & 175 \\
\hline $\begin{array}{c}\text { Deutsche } \\
\text { Sporthochschule } \\
\text { Köln }\end{array}$ & 1.134 & $\begin{array}{c}\text { Universitas } \\
\text { Sumatera Utara }\end{array}$ & 104 \\
\hline $\begin{array}{l}\text { Universidade de } \\
\text { São Paulo }\end{array}$ & 1.027 & $\begin{array}{l}\text { Institut Teknologi } \\
\text { Bandung }\end{array}$ & 76 \\
\hline $\begin{array}{l}\text { University of } \\
\text { Toronto }\end{array}$ & 986 & $\begin{array}{c}\text { Universitas } \\
\text { Negeri Jakarta }\end{array}$ & 57 \\
\hline $\begin{array}{c}\text { Harvard Medical } \\
\text { School }\end{array}$ & 984 & $\begin{array}{l}\text { Universitas } \\
\text { Indonesia }\end{array}$ & 46 \\
\hline $\begin{array}{c}\text { The University of } \\
\text { Queensland }\end{array}$ & 979 & $\begin{array}{c}\text { Universitas } \\
\text { Negeri } \\
\text { Yogyakarta }\end{array}$ & 45 \\
\hline $\begin{array}{c}\text { Norges } \\
\text { idrettshøgskole }\end{array}$ & 916 & $\begin{array}{l}\text { Hasanuddin } \\
\text { University }\end{array}$ & 34 \\
\hline $\begin{array}{c}\text { The University of } \\
\text { Sydney }\end{array}$ & 916 & $\begin{array}{c}\text { Bina Nusantara } \\
\text { University }\end{array}$ & 28 \\
\hline $\begin{array}{l}\text { The University of } \\
\text { British Columbia }\end{array}$ & 850 & $\begin{array}{c}\text { Universitas } \\
\text { Negeri Surabaya }\end{array}$ & 28 \\
\hline La Trobe University & 843 & $\begin{array}{c}\text { Universitas } \\
\text { Sebelas Maret }\end{array}$ & 24 \\
\hline
\end{tabular}

Table 5 shows that Affiliation in research on sports topics at the international level is ranked in the top 3 with Scopus documents above 1,000, namely Loughborough University (1,281), Deutsche Sporthochschule Köln $(1,134)$, and Universidade de São Paulo $(1,027)$. For the Indonesian level, two campuses have documented above 100, namely the University of Education Indonesia (175) and the University of North Sumatra (104). Keywords in sports research topics are presented in Table 6.

Table 6. Keyword research on sports topics

\begin{tabular}{|c|c|c|c|}
\hline \multicolumn{2}{|c|}{$\begin{array}{c}\text { International } \\
(\mathbf{1 4 9 . 9 0 5} \text { Doc.) }\end{array}$} & \multicolumn{2}{c|}{$\begin{array}{c}\text { Indonesia } \\
(\mathbf{1 . 0 8 9} \text { Doc.) }\end{array}$} \\
\hline Keyword & Total & Keyword & Total \\
\hline Human & 61.825 & Sports & 574 \\
\hline Humans & 46.447 & Education & 296 \\
\hline Male & 36.883 & Human & 91 \\
\hline Article & 35.455 & Students & 84 \\
\hline Female & 29.651 & Article & 81 \\
\hline Adult & 27.936 & Indonesia & 76 \\
\hline Sports & 26.936 & Male & 55 \\
\hline Sport & 25.537 & Physical Activity & 51 \\
\hline Adolescent & 16.938 & Health & 49 \\
\hline Athlete & 15.909 & Adult & 48 \\
\hline
\end{tabular}

Table 6 shows the keywords for research on sports topics at the international and Indonesian levels. At the International and Indonesian levels, the top keywords are Human $(60,372)$, Sports (574), and Sports (15).

\subsection{Visualization of Sports Research Trends at the International Level}

There are 149,905 documents (international level) related to sport in the Scopus database, and then researchers visualize research trends on this topic assisted by VOSViewer software. The research trend of Scopus database-based Sports topics is pictured in the form of Network Visualization (NV) in Figure 2a, Density Visualization (NV) in Figure 2b, and Overlay Visualization (NV) in Figure 2c.

Figure 2a shows the overall picture of Scopus databased research on sports topics (2012-2021). Researchers worldwide produced five clusters (shown in red, green, yellow, blue, and purple). The first cluster (red color) is a sport in the study of games, movement, Olympic, action, skills, speed, health care, future direction, and action recognition. The second cluster (green color) is a sport in the patient study, ligament, pain, anterior cruciate ligament rec, ACL, and BMI. The third cluster (blue) is a sport in football, incidence, concussion, chronic traumatic encephalopathy, and athlete exposure. The fourth cluster (purple) studies the player, sprint, match play, speed, validity, high intensity, season, and distance. Cluster five (yellow) is a sport in a systematic review, meta-analysis, science, and controlled trial.

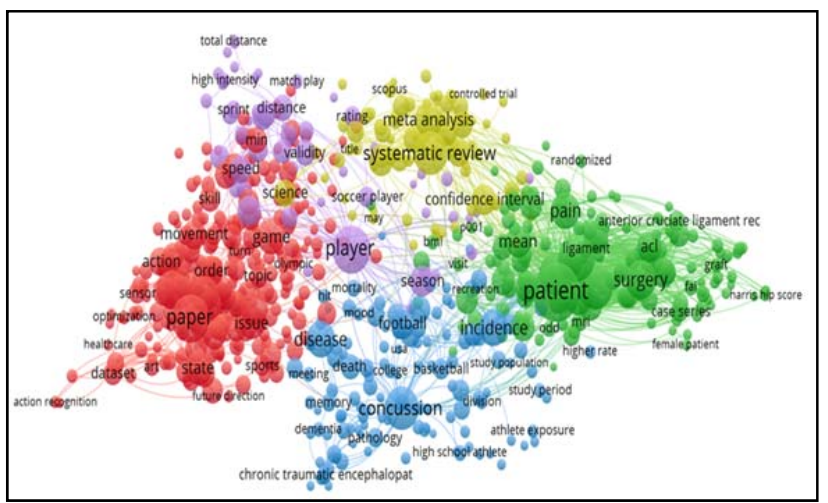

Figure 2a. Network Visualization research trend (International) Sport topic

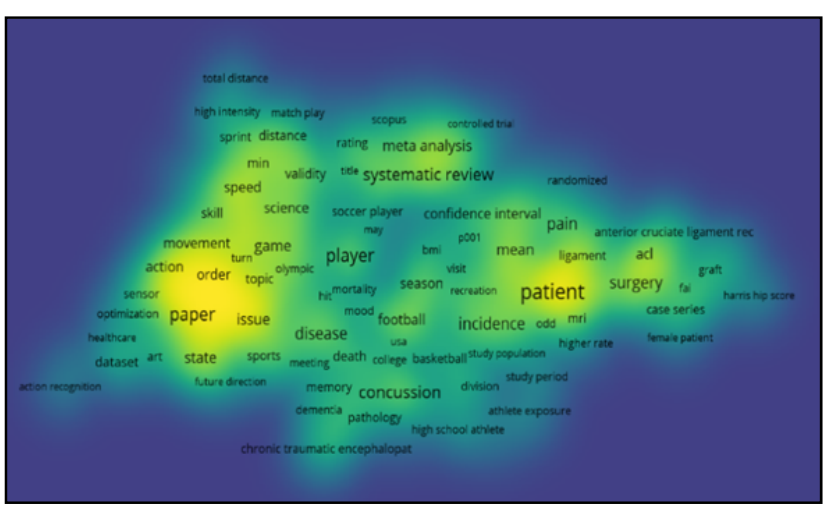

Figure 2b. Density Visualization research trend (International) Sport topic 
Figure $2 \mathrm{~b}$ shows the Density Visualization research trend (International) on sport (2012-2021). Highintensity yellow inpatient studies, surgery, systematic reviews, meta-analyses, and concussions. Potential that can still be developed includes the study of action recognition, chronic traumatic encephalopathy, athlete exposure, future direction, and health care.

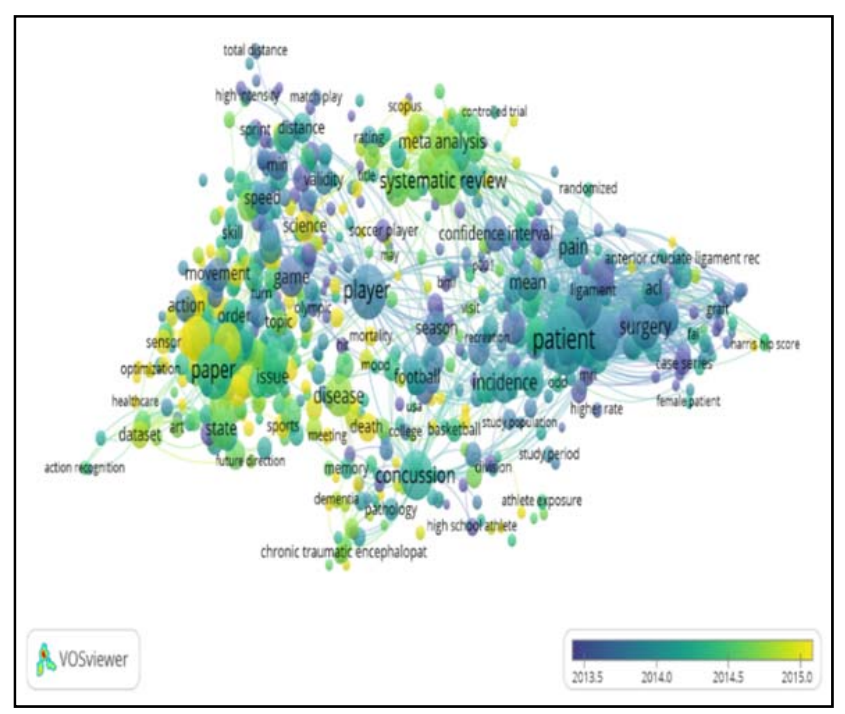

Figure 2c. Overlay Visualization research trend (International) Sport topic

Figure 2c shows the Overlay Visualization of research trends (International) on the topic of sport (2012-2021). The yellow indicator shows the current (latest) research that is being conducted predominantly. There are studies on healthcare, sensors, science, disease, death, and meta-analysis.

\begin{tabular}{l|l|l|}
\hline \multicolumn{1}{|c|}{ Term } & Occurrences $\vee$ & Relevance \\
\hline patient & 351 & 0.63 \\
\hline paper & 226 & 0.87 \\
\hline player & 226 & 0.45 \\
\hline score & 224 & 0.72 \\
\hline study design & 200 & 0.82 \\
\hline month & 185 & 0.65 \\
\hline concussion & 185 & 0.58 \\
\hline systematic review & 185 & 0.48 \\
\hline application & 154 & 1.04 \\
\hline surgery & 151 & 1.18 \\
\hline return & 144 & 0.72 \\
\hline disease & 136 & 0.51 \\
\hline incidence & 135 & 0.41 \\
\hline pain & 133 & 0.76 \\
\hline field & 125 & 0.78 \\
\hline game & 123 & 0.64 \\
\hline meta analysis & 123 & 0.61 \\
\hline state & 122 & 1.00 \\
\hline environment & 117 & 1.00 \\
\hline understanding & 117 & 0.51 \\
\hline
\end{tabular}

Figure 3. Distribution of Terms, Occurrences, and Relevance of research trends (International) on Sport (2012-2021)
Figure 3 shows the distribution of terms, occurrences, and relevance of research trends (international) on the sport topic (2012-2021). Based on the Occurrence data, the studies that appear most frequently in research publications several research trends (International) on Sport topics (2012-2021), including Concussion, Player, Patient, and Systematic Review. In the concussion study, several topics relevant to the concussion include Player, game, issue, attention, brain, football, season, memory, head, baseline, score, systematic review, SRC, Chronic traumatic encephalopathy, high school athlete, athletic trainer, incidence, patient. In the player study, several topics are relevant to players, including concussion, basketball, incidence, football, season, score, player score, speed, match play, high intensity, skill, game, movement, action. In the patient study, there are several topics relevant to the patient, including female patient, concussion, pathology, incidence, disease, order, systematic review, meta-analysis, pain, and ACL. In the systematic review study, several topics are relevant to the review, including concussion, incidence, science, confidence, interval, web score, metaanalysis, pain, and ACL. From the visualization results can be used as an alternative for researchers to get ideas and initial descriptions in research related to sports topics.

\subsection{Visualization of Sports Research Trends at the Indonesian Level}

There are 1,089 documents (Indonesian level) related to the topic of sport in the Scopus database, and then the researcher visualizes research trends on this topic assisted by the VOSViewer software. The research trend of the Scopus database-based Sport topic is visualized in the form of Network Visualization (NV) in Figure 4a, Density Visualization (NV) in Figure $4 \mathrm{~b}$, and Overlay Visualization (NV) in Figure 4c.

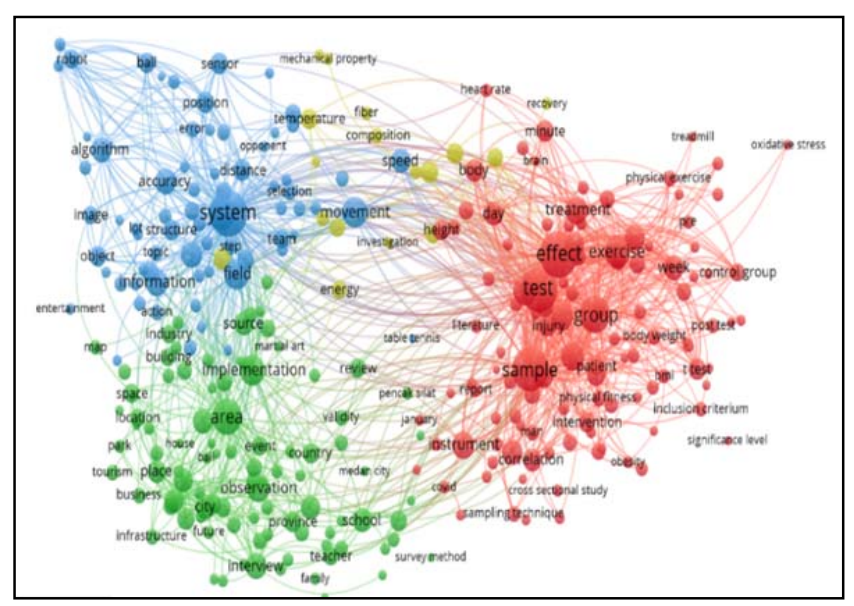

Figure 4a. Network Visualization research trend (Indonesia) Sport topic 
Figure 4a shows the overall picture of Scopus databased research on Sports topics (2012-2021). Researchers in Indonesia produced 4 clusters (shown in red, green, blue, and yellow). The first cluster (red color) is a sport in studying the effect, test, group, patient, body weight, treatment, physical exercise, obesity, inclusion criteria, heart rate, physical fitness, exercise, intervention, treadmile, and oxidative stress. The second cluster (green) is a sport in the study area, implementation, source, event, validity, review, martial arts, school, survey method, interview, infrastructure, tourism, park, martial art, ball, teacher, industry, and table tennis. The third cluster (blue color) is sports on system studies, field, accuracy, distance, information, entertainment, image, object, robot, ball, sensor position, temperature, movement, speed, structure, team, opponent, error, algorithm, and IoT. The fourth cluster (yellow) is sport as a study of mechanical properties, recovery, fiber, composition, and energy.

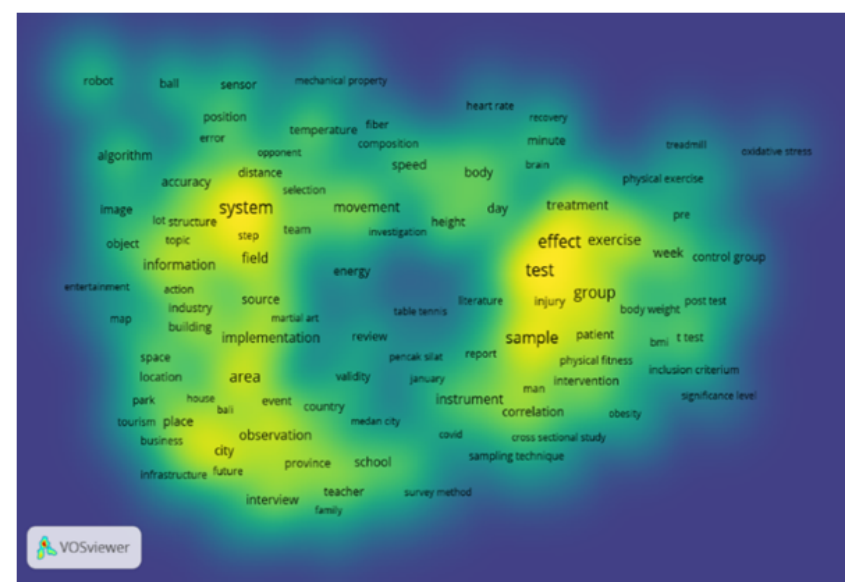

Figure 4b. Density Visualization research trend (Indonesia) Sport topic

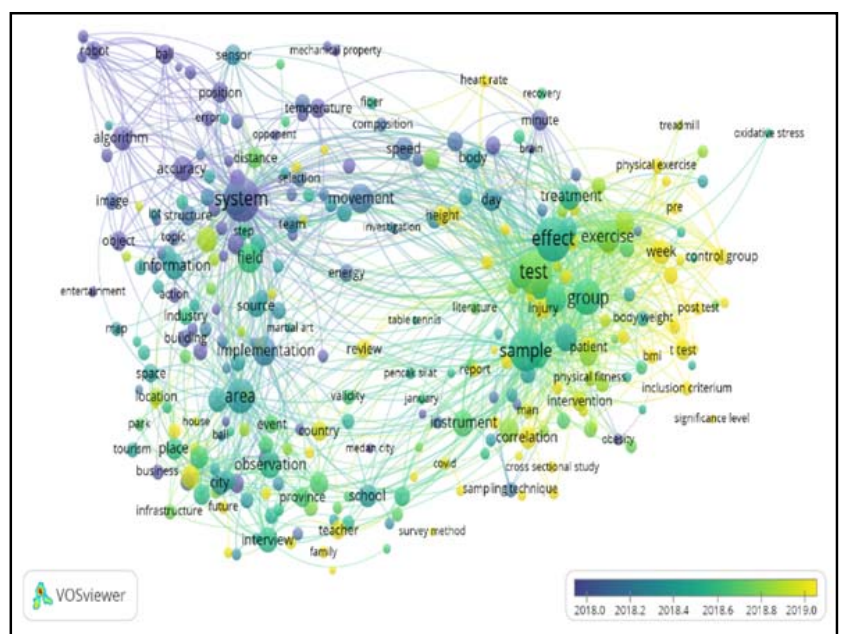

Figure 4c. Overlay Visualization research trend (Indonesia) Sport topic

Figure $4 \mathrm{~b}$ shows the Density Visualization research trend (International) on sport (2012-2021). High intensity in yellow in the study of the system, effect, test, patient experience, injury treatment, sample, intervention, physical fitness, movement, accuracy, and information. Potentials still have great opportunities to develop sports topics in entertainment studies, survey methods, table tennis, martial arts, oxidative stress, physical exercise, recovery, mechanical property, sensors, ball, robot, image, IoT, table tennis, and energy.

Figure $4 c$ shows the Overlay Visualization of research trends (International) on the topic of sport (2012-2021). The yellow color indicator shows the current (latest) research conducted predominantly. There are studies on healthcare, sensors, science, disease, death, and meta-analysis. Figure 5c shows the Overlay Visualization of research trends (International) on the topic of sport (2012-2021). The yellow indicator shows the current (latest) research that is being conducted predominantly. Studies on patient, COVID, review, teacher, intervention, height, physical fitness, heart rate, and injury.

\begin{tabular}{|l|r|r|}
\hline \multicolumn{1}{|c|}{ Term } & Occurrences & \multicolumn{2}{c|}{ Relevance } \\
\hline system & 217 & 0.56 \\
\hline effect & 211 & 0.67 \\
\hline test & 207 & 0.57 \\
\hline sample & 195 & 0.52 \\
\hline paper & 154 & 1.23 \\
\hline group & 142 & 0.90 \\
\hline area & 130 & 0.73 \\
\hline application & 110 & 0.47 \\
\hline exercise & 104 & 1.03 \\
\hline field & 96 & 0.57 \\
\hline implementation & 93 & 0.66 \\
\hline movement & 93 & 0.37 \\
\hline training & 88 & 0.47 \\
\hline subject & 79 & 0.74 \\
\hline instrument & 77 & 0.46 \\
\hline information & 75 & 0.86 \\
\hline treatment & 75 & 0.83 \\
\hline difference & 74 & 0.68 \\
\hline observation & 73 & 0.67 \\
\hline technology & 72 & 0.61 \\
\hline
\end{tabular}

Figure 5. Distribution of Term, Occurrences, and Relevance of research trends (Indonesia) on sport (20122021)

Figure 5 shows the distribution of terms, occurrences, and relevance of research trends (Indonesia) on sport (2012-2021). Based on the Occurrences data, the studies that appear most frequently in several research trends (Indonesia) on the topic of sport (2012-2021), including System, Effect, Test, Sample, Movement, Exercise, Technology, Implementation, Physical Education, Physical Activity, Robot Soccer, and Robots. In the System study, several sports topics relevant to the system include team, movement, field, selection speed, distance, prototype, device, sensor, position, ball, robot, algorithm, accuracy, error, image, vision, action, object, team, body, ration, heart rate, treatment, effect, exercise, sample, test, source, implementation, area, observation, city, government, country, event, map, communication, energy, ratio, information, and outputs. 
In the Effect study, several sports topics relevant to Effect include: test, exercise, treatment, minute, heart rate, body, sample, composition, temperature, recovery, variation, accuracy, intervention, instrument, sampling technique, body weight, intervention, oxidative stress, treadmill, source, industry, area, government, teacher, school, country, city, field, technology, accuracy, system, speed, movement. In the Test study, several sports topics relevant to the Test include: heart rate, minute, body, height, day, treatment, effect, exercise, week, control group, intervention, inclusion criteria, beside technique, instrument, physical exercise, sensor, device, speed, movement, team, field, system, accuracy, implementation, area, validity, school, and technology. In the sample study, several sports topics relevant to the sample include: effect, exercise, treatment, physical exercise, week, minute, body, day, height, physical fitness, intervention, instrument, sampling technique, inclusion criteria, validity, school, society, implementation, area, observation, city, culture, interview, field, technology, accuracy, movement, speed, and temperature.

In the study of Movement, several sports topics relevant to movement include: body, effect, exercise, test, group, sample, motion, distance, position, ball, robot, accuracy, technology, implementation, area, sensor, and algorithms. In the Excercise study, several sports topics relevant to excercise include sensor, system, accuracy, movement, body, heart rate, minute, day, test, treatment, physical exercise, treadmill, week, body weight, effect, test, sample, physical fitness, intervention, woman, instrument, inclusion criteria. In the Technology study, several sports topics relevant to technology include sensors, accuracy, system, device, movement, filed, industry, implementation, community, effect, test, and sample.

In the Implementation study, several sports topics relevant to implementation include robot, ball, position, system, movement, field, accuracy, technology, communication, algorithm, area, government, observation, teacher, school, teacher, city, policy, test, sample, and instrument. In the study of physical education, several sports topics relevant to physical education include: teacher, implementation, effect, test, sample, and instrument. In the study of physical activity, several sports topics relevant to physical activity include: system, school, body, day, effect, exercise, week, group, test, intervention. In the study of robot soccer, several sports topics relevant to robotic soccer include: system, algorithm, ball, position, movement, implementation. In the study of robots, several sports topics relevant to robots include system, object, camera, sensor, distance, algorithm, ball, position, movement, implementation, and implementation. The visualization results in Figure 4 can be used as an alternative for researchers to get ideas and initial descriptions in research related to sports topics.

\subsection{Research Implication}

- Contribute ideas to librarians, researchers, and policy maker in the world to be able to develop sports and be able to produce Scopus documents (reputable journals) to the fullest;

- Provide ideas for librarians and researchers regarding sports research trends;

- Providing information on research trend profiles from Scopus documents related to international and Indonesian sports to librarians, researchers, and policy makers.

\section{Conclusion}

Scientific journal articles dominate publications (Scopus) at the international level. The Indonesian and Unesa levels are dominated by the Conference Paper (Proceedings). The top 10 source titles at the Indonesian level are held by (1) IOP Conference Series Materials Science and Engineering, (2) Journal of Physics Conference Series, and (3) ACM International Conference Proceeding Series. Based on the Scopus Document, it was found that sportsrelated research trends are still a potential topic and are widely studied in the international and Indonesian world. The opportunity for publication in Scopus indexed scientific journals is still wide open. Suppose researchers feel constrained by research data from primary sources in the field. In that case, researchers can do research based on systematic reviews and meta-analyses that have been widely carried out at the international level indexed by Scopus. Recommendations: (1) It is necessary to conduct research that is relevant to the topic of sports that can be published in Scopus indexed journals; (2) Collaboration with other universities in research and publication can be used as an alternative to increasing publication in reputable international journals. 


\section{Acknowledgments}

Thanks for the financial supporting and conducting research in 2021 from the LPPM, Unesa; Grant Number: 855/UN38/HK/PM/2021.

\section{References}

[1]. Andrade, A., Dominski, F. H., \& Vilarino, G. T. (2021). Outdoor Air Quality of Environments Used for Exercise and Sports Practice: An Analysis of Scientific Production through Bibliometric Analysis. Applied Sciences, 11(10), 4540.

[2]. Calabuig-Moreno, F., Gonzalez-Serrano, M. H., Alonso-Dos-Santos, M., \& Gómez-Tafalla, A. (2021). Entrepreneurial ecosystems, knowledge spillovers, and their embeddedness in the sport field: a bibliometric and content analysis. Knowledge Management Research \& Practice, 19(1), 65-83.

[3]. Cui, X. (2021). Academic Influence of China's Sports Social Discipline Based on Bibliometrics. Mobile Information Systems, 2021.

[4]. Gama, J. C. F., Ferreira Neto, A., \& Santos, W. D. (2021). Training To Work On Sports: Bibliometric Characteristics and Collaboration Networks. Movimento, 27.

[5]. Khatra, O., Shadgan, A., Taunton, J., Pakravan, A., \& Shadgan, B. (2021). A Bibliometric analysis of the top cited articles in sports and exercise medicine. Orthopaedic Journal of Sports Medicine, 9(1), 2325967120969902. https://doi.org/10.1177/2325967120969902
[6]. Suprapto, N., Kusnanik, N. W., Iriani, S. S., Wibawa, S. C., Sujarwanto, S., Yulianto, B., ... \& Nurhasan, N. (2021). The Comparison of Scimago Institutions Rankings (SIR), Scopus, and SINTA Profile: A Case of the Top Indonesian Institutions. Library Philosophy and Practice (e-journal). 5788.

[7]. Glanzel, W. (2005). Bibliometrics as a research field. Course script. Leuven, Belgium: Katholieke Universiteit Leuven.

[8]. Tianji, H., Shengdong, Y., Hao, L., Chunyang, Z., Zhongqi, D., Weiyang, Z., \& Xiaoji, L. (2020). Mapping knowledge domains of bibliometrics regarding percutaneous vertebroplasty and percutaneous kyphoplasty based on VOSviewer. Chinese Journal of Tissue Engineering Research, 24(15), 2410.

[9]. Xie, L., Chen, Z., Wang, H., Zheng, C., \& Jiang, J. (2020). Bibliometric and visualized analysis of scientific publications on atlantoaxial spine surgery based on Web of Science and VOSviewer. World neurosurgery, 137, 435-442.

[10]. Hamidah, I., Sriyono, S., \& Hudha, M. N. (2020). A Bibliometric analysis of Covid-19 research using VOSviewer. Indonesian Journal of Science and Technology, 34-41.

[11]. Huang, T., Wu, H., Yang, S., Su, B., Tang, K., Quan, Z., ... \& Luo, X. (2020). Global trends of researches on sacral fracture surgery: a bibliometric study based on VOSviewer. Spine, 45(12), E721-E728. 